\title{
Relationship between Family History of Diabetes Mellitus and Gestational Diabetes Mellitus: A Meta-Analysis
}

\author{
Ummu Fatihah Ammutammima'), Didik Gunawan Tamtomo²), Bhisma Murti1) \\ 1)Masters Program in Public Health, Universitas Sebelas Maret \\ 2)Faculty of Medicine, Universitas Sebelas Maret
}

Background: Gestational Diabetes Mellitus (GDM) is the most common metabolic disorder first diagnosed during pregnancy. According to the American Diabetes Association (ADA) in 2006, GDM occurred in 7\% of pregnancies each year. Family history of diabetes is an important risk factor for GDM. The relationshipbetween family history of DM and GDM has been investigated in several primary studies with several contradictions in the outcome. Therefore, this study aimed to determine the relationship between family history of diabetes and GDM using a meta-analysis method.

Subjects and Method: The meta-analysis was conducted by systematically reviewing articles published from 2007 to 2020 from the Pubmed, Google Scholar, Science Direct, and ResearchGate databases. The keywords were "Risk factor" OR "family history" OR "family history DM") AND "GDM" AND "cross sectional". The article search was carried out using PICO: the study population was pregnant women, the intervention/exposure was family history of DM, the comparison was no family history of DM, and the outcome was GDM. The article search was carried out for one month. The articles included in this study were full-text articles with a cross-sectional design. The articles were reviewed using the PRISMA flow diagram guidelines. This study used Revman 5.3 Software to analyze the articles.

Results: Family history of DM increased the risk of Gestational Diabetes Mellitus $(\mathrm{aOR}=$ 2.02; 95\% CI= 1.54 - 2.67; $\mathrm{p}<0.001$ ). This study used 11 articles from Ethiopia, Cameroon, Peru, Iran, Pakistan, Malaysia, Kuwait, Saudi Arabia, and India.

Conclusion: Family history of diabetes mellitus increases the risk of gestational diabetes mellitus.

Keywords: Gestational diabetes mellitus, Family history of diabetes

\section{Correspondence: \\ Ummu fatihah Ammutammima. Masters Pro- gram in Public Health, Universitas Sebelas Maret, Jl. Ir. Sutami 36A, Surakarta 57126, Central Java. Email: ummuftha64@gmail.com. Mobile: 081717252573.}

\section{Cite this as:}

Ammutammima UF, Tamtomo DG, Murti B (2021). Relationship between Family History of Diabetes Mellitus and Gestational Diabetes Mellitus: A Meta-Analysis. Indones J Med. 06(01): 71-81. https://doi.org/10.26911/theijmed.2021.06.01.08.

cc (i) (-) Indonesian Journal of Medicine is licensed under a Creative Commons cc) $\mathrm{Br}$ No SA Attribution-NonCommercial-ShareAlike 4.0 International License.

\begin{abstract}
BACKGROUND
Gestational Diabetes Mellitus (GDM) is defined as glucose intolerance identified during pregnancy (Sugianto, 2016). This situation usually occurs at 24 weeks of gestation and some of the patient's blood glucose levels will go back to normal after delivery (Ministry of Health RI, 2008). How-
\end{abstract}

ever, in almost half of the incidence, diabetes will recur (Nurrahmani, 2012).

GDM in mothers can increase the risk of having diabetes by $3-5 \%$ in the future. This can affect the unborn baby, namely the fetus who died in the womb, macrosomia, late lung maturation, birth trauma, growth retardation, congenital malformation, and neonatal death. Newborns were also at high 
risk of obesity, glucose intolerance, and diabetes as adolescents (Bilous et al, 2014).

GDM has become a global problem based on the rate and its impact (Osgood et al, 2011). According to the American Diabetes Association (ADA) in 2006, GDM occurred in $7 \%$ of pregnancies each year. The prevalence of GDM varied from 1\%$14 \%$. This rate depended on the population studied and the screening criteria used (ADA, 2006).

High blood sugar levels in pregnant women can be caused by several factors such as age, genetics, smoking habits, or exercise, sex and age, anatomy or constitution, physical, chemical, biological, psychological, socio-cultural conditions, and behavioral and nutrition (Begum et al, 2017).

Family history of DM is one of the genetic factors affecting a person to have GDM. A person who has a family of Diabetes Mellitus has a 3 times risk of having Diabetes Mellitus. A family history of DM has a risk of having DM by $15 \%$. If both parents have diabetes mellitus, the risk of having diabetes mellitus is $75 \%$. The risk of having DM from the mother was 10-30\% greater than the father (Zhang et al, 2015).

Based on the result of the previous study conducted by Sulistiyah, the medical factor of GDM in pregnant women is a family history of DM (49\%). Some other literature added that a family history of DM was also likely related to GDM in pregnant women (Sulistiyah, 2015).

A family history of type 2 DM would have a $15 \%$ possibility of having DM and the risk of having glucose intolerance (the inability to metabolize carbohydrates normally) by 30\% (Damayanti, 2015).

Therefore, the researcher was interested in investigating the relationship between family history of DM and GDM. The data obtained would be analyzed using a meta-analysis by synthesizing the results.

\section{SUBJECTS AND METHOD}

\section{Study Design}

This was a systematic review and a metaanalysis. The meta-analysis was carried out by systematically reviewing articles published from 2007 to 2020 from the Pubmed, Google Scholar, Science Direct, and Research Get databases. The keywords were "Risk factor" OR "family history" OR "family history DM") AND "GDM" AND "cross sectional".

\section{Inclusion Criteria}

The author developed inclusion criteria: full-text articles in English and Indonesian languages with a cross-sectional study design. The study subjects were pregnant women aged $>28$ years old and pregnant women with a BMI of $>27 \mathrm{~kg} / \mathrm{m}^{2}$. The outcome analyzed was Gestational Diabetes Mellitus. The study used multivariate analysis with an adjusted Odds Ratio. The outcome was Gestational Diabetes Mellitus.

\section{Exclusion Criteria}

The exclusion criteria were non-cross-sectional study, non-full-text articles, published before 2007, non-English and Indonesian languages, non-multivariate analysis study.

\section{Operational Definition of Variables}

The article search was carried out by considering the eligibility criteria defined using the PICO model. The population of this study was pregnant women. The intervention was a family history of DM. The comparison was no family history of DM. The outcome was Gestational Diabetes Mellitus.

Family history of DM was the main risk factor in women for having GDM. This study used a questionnaire with a categorical scale as the measurement instrument.

Gestational Diabetes Mellitus was a carbohydrate intolerance condition that developed first diagnosedduring pregnancy. This study used a glucose test with a continous scale as the measuring instrument. 


\section{Data Analysis}

The articles were collected using a PRISMA diagram. The data analysis was conducted using RevMan 5 published by the Cochrane Collaboration. RevMan was used to calculate the overall adjusted Odds Ratio (aOR), configured the $95 \%$ confidence interval (CI) using the effects model, and $\mathrm{I}^{2}$ or heterogeneity of the data.

\section{RESULTS}

The article review process is in the PRISMA flow diagram in Figure 1. This meta-analysis analyzed 11 primary studies conducted in Ethiopia, Cameroon, Peru, Iran, Pakistan, Malaysia, Kuwait, Saudi Arabia, and India.

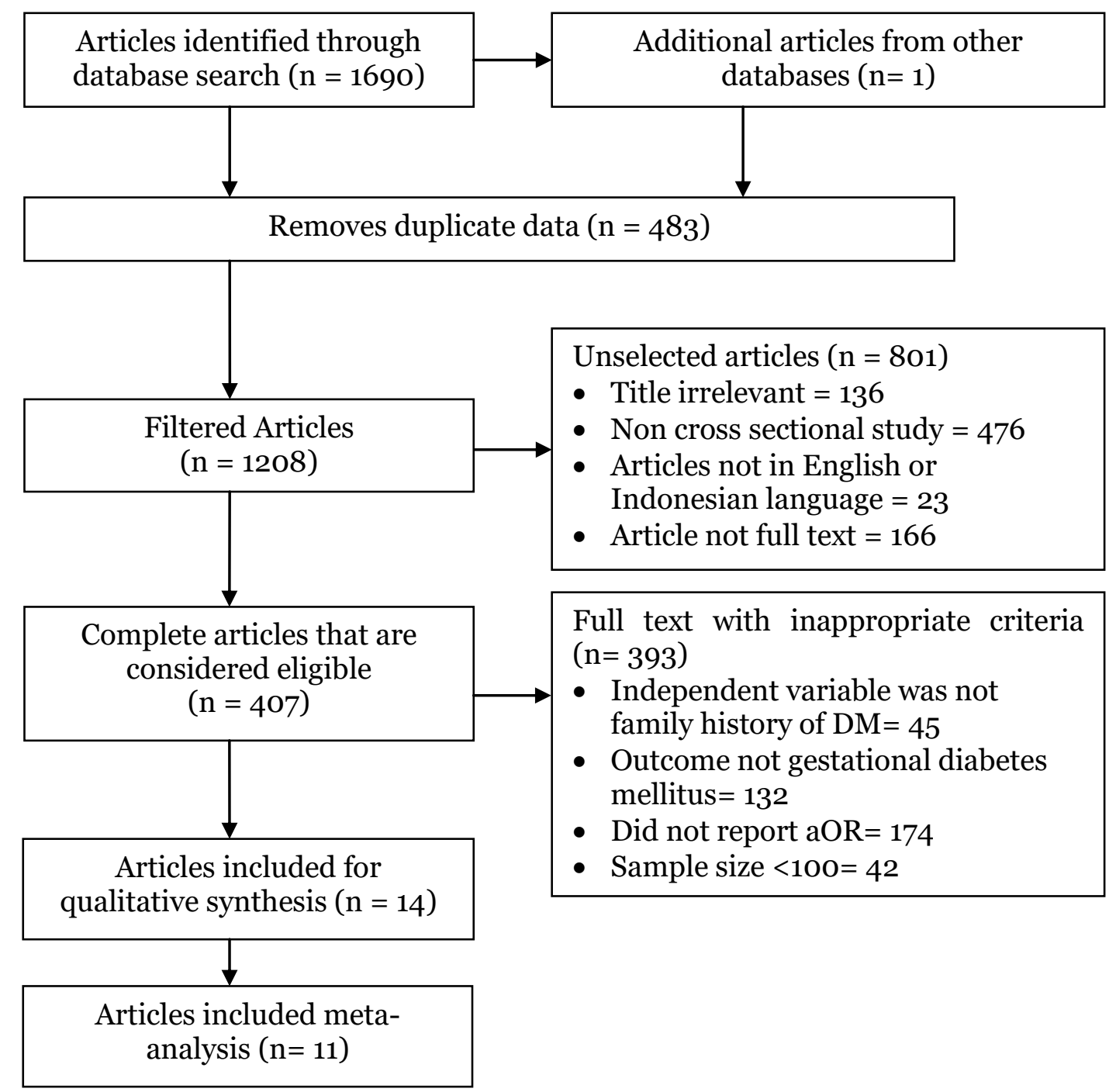

Figure 1. PRISMA flow diagram 
Table 2. The description of the primary study included in the meta-analysis The relationship between family history of DM and Gestational Diabetes Mellitus

\begin{tabular}{|c|c|c|c|c|c|c|c|}
\hline $\begin{array}{c}\text { Author } \\
\text { (Year) }\end{array}$ & Location & $\begin{array}{l}\text { Study } \\
\text { Design }\end{array}$ & Sample & $\begin{array}{c}\mathbf{P} \\
\text { Population } \\
\end{array}$ & $\begin{array}{c}\text { I } \\
\text { Intervention }\end{array}$ & $\begin{array}{c}\mathrm{C} \\
\text { Comparison } \\
\end{array}$ & $\begin{array}{c}\text { O } \\
\text { Outcome }\end{array}$ \\
\hline $\begin{array}{l}\text { Muche et al, } \\
2019\end{array}$ & $\begin{array}{l}\text { Northwest } \\
\text { Ethiopia } \\
\text { (Africa) }\end{array}$ & $\begin{array}{l}\text { Cross - } \\
\text { sectional }\end{array}$ & 1027 & $\begin{array}{l}\text { Pregnant } \\
\text { Women }\end{array}$ & $\begin{array}{l}\text { Maternal age (> } 25 \text { years), } \\
\text { marital status (Married), } \\
\text { education level(Senior High } \\
\text { School), obesity (MUAC } \\
\geq 28 \text { ), hada history of GDM, } \\
\text { hada history of macrosomic } \\
\text { infants, had a history of } \\
\text { abortion, had a history of } \\
\text { stillbirth, } \\
\text { *had afamily history of DM* }\end{array}$ & $\begin{array}{l}\text { Maternal age(<25 years), } \\
\text { marital status (Single), } \\
\text { education level(elementary } \\
\text { school, obesity (MUAC } \\
<28 \text { ), no history of GDM, } \\
\text { no history of macrosomic } \\
\text { infants, no history of } \\
\text { abortion, no history of } \\
\text { stillbirth, } \\
{ }^{*} \text { no family history of } \mathrm{DM}^{*}\end{array}$ & $\begin{array}{l}\text { Gestational } \\
\text { Diabetes Mellitus } \\
\text { (GDM) }\end{array}$ \\
\hline $\begin{array}{l}\text { Wolka et al, } \\
2018\end{array}$ & $\begin{array}{l}\text { Southern } \\
\text { Ethiopia } \\
\text { (Africa) }\end{array}$ & $\begin{array}{l}\text { Cross- } \\
\text { sectional }\end{array}$ & 518 & $\begin{array}{l}\text { Pregnant } \\
\text { Women }\end{array}$ & $\begin{array}{l}\text { Maternal age ( }>35 \text { years), } \\
\text { marital status (Married), } \\
\text { obesity (MUAC } \geq 30 \text { ), had a } \\
\text { history of GDM, had a his- } \\
\text { tory of stillbirth/ mis- } \\
\text { carriage, had a history of } \\
\text { abortion, } \\
\text { *had a family history of } \mathrm{DM}^{*}\end{array}$ & $\begin{array}{l}\text { Maternal age(16-20 years), } \\
\text { marital status (Single), } \\
\text { obesity(MUAC <30), had } \\
\text { the history of GDM, had a } \\
\text { history of stillbirth/ mis- } \\
\text { carriage, no history of } \\
\text { abortion, } \\
\text { *no family history of DM* }\end{array}$ & $\begin{array}{l}\text { Gestational } \\
\text { Diabetes Mellitus } \\
(\text { GDM) }\end{array}$ \\
\hline $\begin{array}{l}\text { Egbe et al, } \\
2017\end{array}$ & $\begin{array}{l}\text { Cameroon } \\
\text { (Africa) }\end{array}$ & $\begin{array}{l}\text { Cross- } \\
\text { sectional }\end{array}$ & 200 & $\begin{array}{l}\text { Pregnant } \\
\text { Women }\end{array}$ & $\begin{array}{l}\text { Age (>19 years), Type } 2 \text { DM, } \\
\text { Duration of diabetes ( }>6 \\
\text { years), normal systolic blood } \\
\text { pressure level (>140mmhg), } \\
\text { *hada family history of DM* }\end{array}$ & $\begin{array}{l}\text { Age }(<19 \text { years), Type } 1 \mathrm{DM} \text {, } \\
\text { Duration of diabetes }(<6 \\
\text { years), Normal systolic } \\
\text { blood pressure level ( }<140 \\
\text { mmhg), * nofamily history } \\
\text { of DM* }\end{array}$ & $\begin{array}{l}\text { Gestational } \\
\text { Diabetes Mellitus } \\
\text { (GDM) }\end{array}$ \\
\hline $\begin{array}{l}\text { Torrealva et } \\
\text { al., } 2018\end{array}$ & $\begin{array}{l}\text { Peru } \\
\text { (America) }\end{array}$ & $\begin{array}{l}\text { Cross- } \\
\text { sectional }\end{array}$ & 1300 & $\begin{array}{l}\text { Pregnant } \\
\text { Women }\end{array}$ & $\begin{array}{l}\text { Maternal age ( } \geq 35 \text { years), } \\
\text { marital status (Married), } \\
\text { maternal education }(>12 \\
\text { years), maternal BMI } \geq 30 \\
\mathrm{~kg} / \mathrm{m}^{2}, \text { had depression, }\end{array}$ & $\begin{array}{l}\text { Maternal age }(<19 \text { years }) \text {, } \\
\text { marital status (Single), } \\
\text { maternal education }(<9 \\
\text { years }), \text { maternal BMI }<25 \\
\mathrm{~kg} / \mathrm{m}^{2}, \text { no depression, }\end{array}$ & $\begin{array}{l}\text { Gestational } \\
\text { Diabetes Mellitus } \\
\text { (GDM) }\end{array}$ \\
\hline
\end{tabular}




\begin{tabular}{|c|c|c|c|c|c|c|c|}
\hline $\begin{array}{l}\text { Author } \\
\text { (Year) }\end{array}$ & Location & $\begin{array}{l}\text { Study } \\
\text { Design }\end{array}$ & Sample & $\begin{array}{c}\mathbf{P} \\
\text { Population }\end{array}$ & $\begin{array}{c}\text { I } \\
\text { Intervention }\end{array}$ & $\begin{array}{c}\mathrm{C} \\
\text { Comparison }\end{array}$ & $\begin{array}{c}\text { O } \\
\text { Outcome }\end{array}$ \\
\hline $\begin{array}{l}\text { Nezhad et } \\
\text { al, } 2007\end{array}$ & $\begin{array}{l}\text { Iran } \\
\text { (Asia) }\end{array}$ & $\begin{array}{l}\text { Cross- } \\
\text { sectional }\end{array}$ & 2416 & $\begin{array}{l}\text { Pregnant } \\
\text { Women }\end{array}$ & $\begin{array}{l}\text { *had afamily history of DM* } \\
\text { Maternal age ( } 35-45 \text { years), } \\
\text { BMI (>27kg/m2), had the } \\
\text { history of macrosomic } \\
\text { infants, had a history of } \\
\text { abortion, had a history of } \\
\text { stillbirth, } \\
\text { *had afamily history of } \mathrm{DM}^{*}\end{array}$ & $\begin{array}{l}\text { *nofamily history of } \mathrm{DM}^{*} \\
\text { Maternal age }(15-24 \text { years }) \text {, } \\
\text { BMI }(\leq 27 \mathrm{~kg} / \mathrm{m} 2) \text {, no } \\
\text { history of macrosomic } \\
\text { infants, no history of } \\
\text { abortion, no history of } \\
\text { stillbirth, } \\
\text { *nofamily history of } \mathrm{DM}^{*}\end{array}$ & $\begin{array}{l}\text { Gestational } \\
\text { Diabetes Mellitus } \\
\text { (GDM) }\end{array}$ \\
\hline $\begin{array}{l}\text { Mohammad } \\
\text { zadeh et al, } \\
2015\end{array}$ & $\begin{array}{l}\text { Iran } \\
\text { (Asia) }\end{array}$ & $\begin{array}{l}\text { Cross- } \\
\text { sectional }\end{array}$ & 1276 & $\begin{array}{l}\text { Pregnant } \\
\text { Women }\end{array}$ & $\begin{array}{l}\text { Maternal age (> 30 years), } \\
\text { Height }(<158 \mathrm{Cm}), \text { Weight } \\
\text { (> 73kg), BMI }(29 \mathrm{~kg} / \mathrm{m} 2) \text {, } \\
\text { Systolic Blood Pressure } \\
\text { (107.6 mmHg), Diastolic } \\
\text { Blood Pressure (66.8 } \\
\text { mmHg), had a history of } \\
\text { GDM, had a history of hyper- } \\
\text { tension during pregnancy, } \\
\text { had a macrosomia, had a } \\
\text { history of abortion and still- } \\
\text { birth, had congenital malfor- } \\
\text { mation, *had afamily history } \\
\text { of DM* }\end{array}$ & $\begin{array}{l}\text { Maternal age }(<27 \text { years }) \text {, } \\
\text { Height }(>159 \mathrm{Cm}), \text { Weight } \\
(<64 \mathrm{~kg}), \mathrm{BMI}\left(25 \mathrm{~kg} / \mathrm{m}^{2}\right) \text {, } \\
\text { Systolic Blood Pressure } \\
\text { (104.7 mmHg), Diastolic } \\
\text { Blood Pressure ( } 66.2 \\
\text { mmHg), no history of GDM, } \\
\text { no history of hypertension } \\
\text { during pregnancy, no } \\
\text { history of macrosomia, no } \\
\text { history of abortion and still- } \\
\text { birth, no congenital } \\
\text { malformation, *no family } \\
\text { history of DM* }\end{array}$ & $\begin{array}{l}\text { Gestational } \\
\text { Diabetes Mellitus } \\
\text { (GDM) }\end{array}$ \\
\hline $\begin{array}{l}\text { Hossain et } \\
\text { al, } 2017\end{array}$ & $\begin{array}{l}\text { Pakistan } \\
\text { (Asia) }\end{array}$ & $\begin{array}{l}\text { Cross- } \\
\text { sectional }\end{array}$ & 1030 & $\begin{array}{l}\text { Pregnant } \\
\text { Women }\end{array}$ & $\begin{array}{l}\text { Maternal age ( }>26 \text { years), } \\
\text { BMI (>25kg/m2), had the } \\
\text { history of macrosomic } \\
\text { infants, had a history of } \\
\text { GDM, *had a family history } \\
\text { of DM* }\end{array}$ & $\begin{array}{l}\text { Maternal age }(<26 \text { years }) \text {, } \\
\text { BMI }(<25 \mathrm{~kg} / \mathrm{m} 2) \text {, no } \\
\text { history of macrosomic } \\
\text { infants,no history of GDM, } \\
\text { *no family history of DM* }\end{array}$ & $\begin{array}{l}\text { Gestational } \\
\text { Diabetes }\end{array}$ \\
\hline $\begin{array}{l}\text { Lee et al, } \\
2020\end{array}$ & $\begin{array}{l}\text { Malaysia } \\
\text { (Asia) }\end{array}$ & $\begin{array}{l}\text { Cross- } \\
\text { sectional }\end{array}$ & 526 & $\begin{array}{l}\text { Pregnant } \\
\text { Women }\end{array}$ & $\begin{array}{l}\text { Maternal age (19-45 years), } \\
\text { marital status (Married), } \\
\text { education level (Tertiary), } \\
\text { BMI during pregnancy (16- }\end{array}$ & $\begin{array}{l}\text { Maternal age (< } 19 \text { years), } \\
\text { marital status (Single/ } \\
\text { others), education level } \\
\text { (Primary), BMI during }\end{array}$ & $\begin{array}{l}\text { Gestational } \\
\text { Diabetes Mellitus } \\
\text { (GDM) }\end{array}$ \\
\hline
\end{tabular}




\begin{tabular}{|c|c|c|c|c|c|c|c|}
\hline $\begin{array}{l}\text { Author } \\
\text { (Year) }\end{array}$ & Location & $\begin{array}{l}\text { Study } \\
\text { Design }\end{array}$ & Sample & $\begin{array}{c}\mathbf{P} \\
\text { Population }\end{array}$ & $\begin{array}{c}\text { I } \\
\text { Intervention }\end{array}$ & $\begin{array}{c}\mathrm{C} \\
\text { Comparison }\end{array}$ & $\begin{array}{c}\text { O } \\
\text { Outcome }\end{array}$ \\
\hline & & & & & $\begin{array}{l}\text { 58.5), had a family history of } \\
\text { depression/anxiety, had a } \\
\text { history of hypertension, had } \\
\text { a history of GDM, had a } \\
\text { history of stillbirth/ mis- } \\
\text { carriage, had a family history } \\
\text { of hypertension, } \\
\text { *had a family history of DM* }\end{array}$ & $\begin{array}{l}\text { pregnancy }(<16) \text {, no family } \\
\text { history of depression/ } \\
\text { anxiety, no history of hyper- } \\
\text { tension, no history of GDM, } \\
\text { no history of stillbirth/ mis- } \\
\text { carriage, no family history } \\
\text { of hypertension, } \\
\text { *no family history of DM* }\end{array}$ & \\
\hline $\begin{array}{l}\text { Groof et al, } \\
2019\end{array}$ & $\begin{array}{l}\text { Kuwait } \\
\text { (Asia) }\end{array}$ & $\begin{array}{l}\text { Cross- } \\
\text { sectional }\end{array}$ & 947 & $\begin{array}{l}\text { Pregnant } \\
\text { Women }\end{array}$ & $\begin{array}{l}\text { Maternal age ( }>25 \text { years), } \\
\text { marital status (Married), } \\
\text { education level (College or } \\
\text { university), obesity (MUAC } \\
\geq 30 \text { ), had a history of GDM, } \\
\text { had a history of stillbirth/ } \\
\text { miscarriage, } \\
\text { *had afamily history of DM* }\end{array}$ & $\begin{array}{l}\text { Maternal age (<25 years), } \\
\text { marital status (Single/ } \\
\text { others), education level } \\
\text { (Middle school), obesity } \\
\text { (MUAC <30), no history of } \\
\text { GDM, no history of still- } \\
\text { birth/miscarriage, } \\
\text { *no family history of DM* }\end{array}$ & $\begin{array}{l}\text { Gestational } \\
\text { Diabetes Mellitus } \\
\text { (GDM) }\end{array}$ \\
\hline $\begin{array}{l}\text { Wahabi, } \\
2018\end{array}$ & $\begin{array}{l}\text { Saudi } \\
\text { Arabia } \\
\text { (Asia) }\end{array}$ & $\begin{array}{l}\text { Cross- } \\
\text { sectional }\end{array}$ & 316 & $\begin{array}{l}\text { Pregnant } \\
\text { Women }\end{array}$ & $\begin{array}{l}\text { Maternal age }(>30 \text { years }) \\
\text { BMI at pre-pregnancy }(\geq 30 \\
\left.\mathrm{kg} / \mathrm{m}^{2}\right) \\
{ }^{*} \text { had a history of } \mathrm{T} 2 \mathrm{DM}^{*}\end{array}$ & $\begin{array}{l}\text { Maternal age }(<30 \text { years }), \\
\text { BMI at pre-pregnancy }(\geq \\
\left.25 \mathrm{~kg} / \mathrm{m}^{2}\right) \\
* \text { no history of } \mathrm{T} 2 \mathrm{DM}^{*}\end{array}$ & $\begin{array}{l}\text { Gestational } \\
\text { Diabetes Mellitus } \\
\text { (GDM) }\end{array}$ \\
\hline $\begin{array}{l}\text { Begum et al, } \\
2017\end{array}$ & $\begin{array}{l}\text { India } \\
\text { (Asia) }\end{array}$ & $\begin{array}{l}\text { Cross- } \\
\text { sectional }\end{array}$ & 303 & $\begin{array}{l}\text { Pregnant } \\
\text { Women }\end{array}$ & $\begin{array}{l}\text { Maternal age (> 30 years), } \\
\text { education level (Graduate), } \\
\text { education }>60 \text { kg,BMI }(\geq 25) \text {, } \\
\text { had a family history of GDM, } \\
\text { *had a family history of DM* }\end{array}$ & $\begin{array}{l}\text { Maternal age }(<30 \text { years), } \\
\text { education level (Primary), } \\
\text { weight }<60 \text { kg, BMI }(<25) \text {, } \\
\text { no family history of GDM, } \\
\text { *no family history of DM* }\end{array}$ & $\begin{array}{l}\text { Gestational } \\
\text { Diabetes Mellitus } \\
\text { (GDM) }\end{array}$ \\
\hline
\end{tabular}

*Variables included in the meta-analysis study* 
Ammutammima et al./ Family History of Diabetes Mellitus and Gestational Diabetes Mellitus

\section{a. Forest plot}

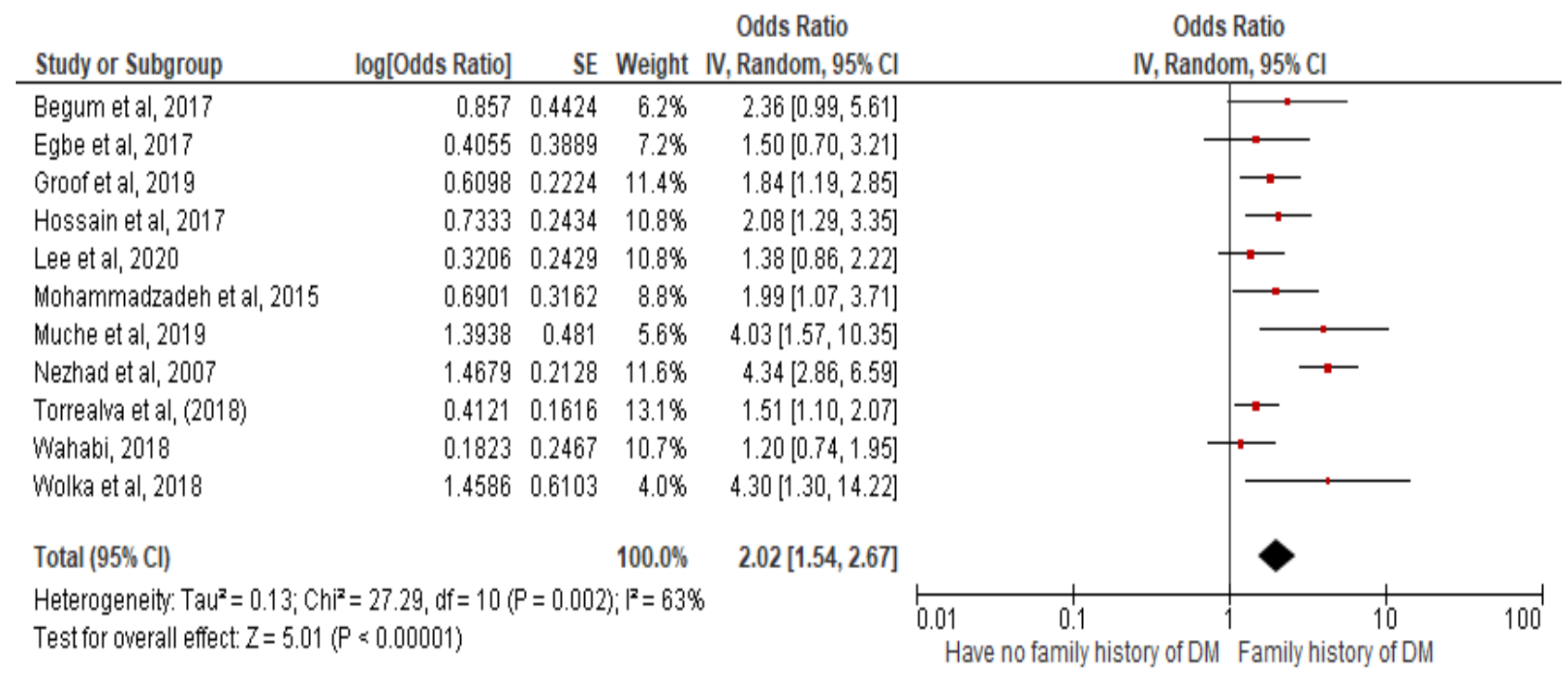

Figure 3. The forest plot of the relationship between family history of DM and Gestational Diabetes Mellitus

\section{b. Funnel plot}

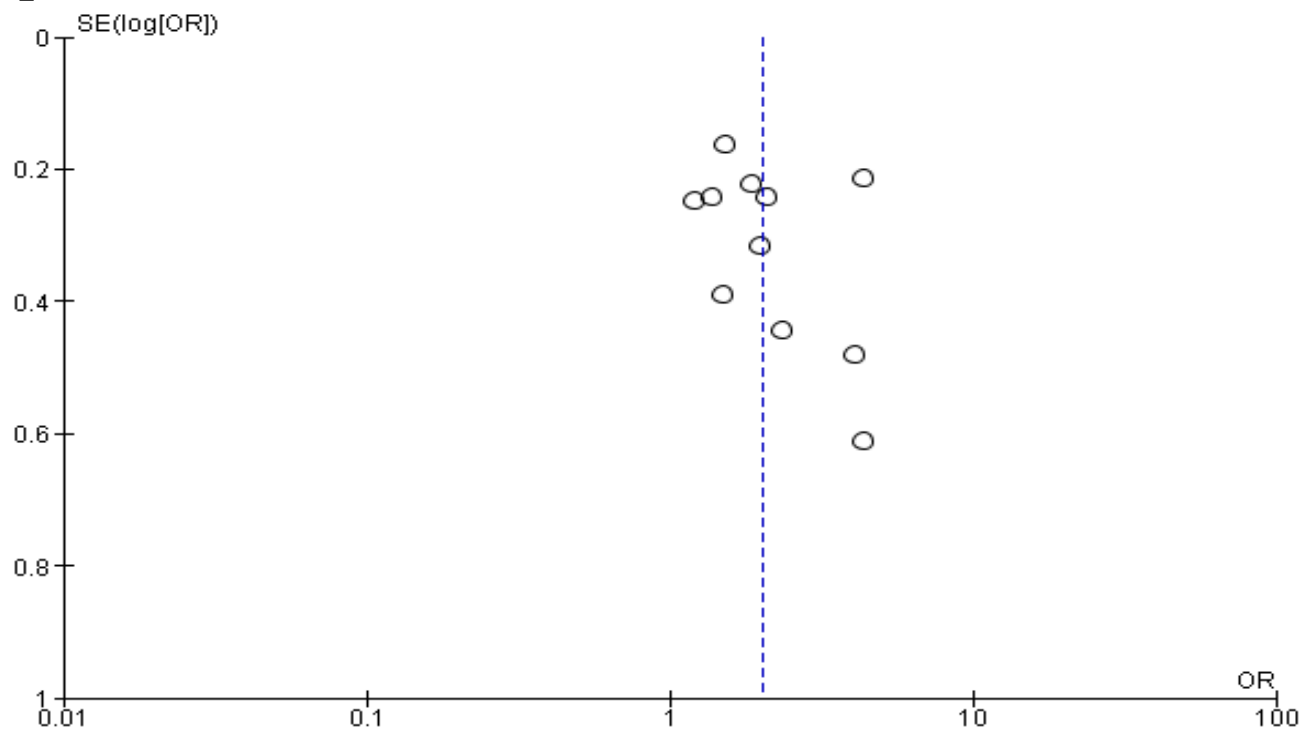

Figure 4. The funnel plot of the relationship between family history of DM and gestational diabetes mellitus

The forest plot showed that pregnant women with a family history of DM could increase the risk of Gestational Diabetes Mellitus 2.02 times compared to pregnant women who did not have a history of DM ( $\mathrm{p}<0.001)$. The heterogeneity of the study data showed that $\mathrm{I}^{2}=63 \%$. Therefore, the distribution of the data was heterogeneous (random effect model).

The funnel plot showed a publication bias characterized by an asymmetry of the right and left plots where 4 plots were on the right and 4 plots were on the left. The plot on the left of the graph had a standard 
error between $\mathrm{o}$ and 0.4 . Besides, the plot on the right had a standard error between o.2and 0.6. Bias occurred from the imbalance among the distances of each study on both the right and left of the funnel plot where 2 plots were on the right and 3 plots were on the left. The plot on the left of the graph had a standard error between 0.4 and 1. Besides, the plot on the right had a standard error between 0.6 and o.8. Bias occurred from the imbalance among the distances of each study on both the right and left of the funnel plot.

\section{DISCUSSION}

DM develops slowly and progressively so that there is no early detection due to clinical figures had by sufferers such as the triad of diabetes mellitus, namely polyuria (frequent urination), drinking and eating a lot. Diabetes control efforts aimed to prevent microvascular and macrovascular complications (Prasetyowati, 2018)

The development of DM could also be seen from the DM risk group. DM did not only attack the elderly but also the productive age. In many cases, DM attacked pregnant women. Insulin disorders in pregnant women were called Gestational Diabetes Mellitus.

This study was a systematic study and a meta-analysis. It focused on the relationship between family history of Diabetes Mellitus and Gestational Diabetes Mellitus. The results of the systematic review and a meta-analysis on the primary study showed an epidemiological study design with a larger sample and different demographic characteristics in both developed and developing countries, thus providing a basis for concluding that family history of DM was statistically related to the incidence of Gestational Diabetes Mellitus.

This systematic review and metaanalysis study used studies that controlled confounding factors.It could be seen from the inclusion criteria of the primary study. It was the result of multivariate analysis in the form of adjusted Odds Ratio (aOR). According to Murti (2018), the confounding factor was the combination of the estimated relationships between exposure and the disease studied, by other factors associated, both with disease and exposure. Confounding factors affected the relationship or effect of exposure to the occurrence of the disease estimated by the study. It was not the same as the relationship or effect that occurred in the target population (invalid study result).

The estimation of the combination between family history of DM and GDM was processed using the RevMan 5.3 application with the generic inverse variance method. This method aimed to analyze the data in the form of rate, time-to-event, hazard ratio, ordinal scale, adjusted estimate, difference of mean, or ratio of mean.

The results of the systematic study and meta-analysis were presented in the form of a forest plot and a funnel plot.The forest plot provided an overview of the information from each of the studies examined in the meta-analysis and the estimation of the overall results (Murti, 2018). The forest plot showed visually the amount of variation (heterogeneity) among study results (Akobeng in Murti, 2018).

A funnel plot was a diagram in a meta-analysis that aimed to demonstrate possible publication bias. The funnel plot showed the relationship between the effect size of the study and the sample size or standard error of the effect size of the various studies examined (Murti, 2018). The funnel plot showed visually the amount of variation (heterogeneity) (Akobeng, 2005 in Murti, 2018). The funnel plot showed the relationship between the effect size of the study and the sample size of the 
various studies examined which could be measured in several different ways (Murti, 2018).

\section{Family history of DM and Gestational Diabetes Mellitus}

The results of the meta-analysis of 11 articles regarding the relationship between family history of DM and GDM were summarized in a forest plot. The forest plot in Figure 4.1 showed that pregnant women with a family history of DM increased the risk of GDM by 2.02 times compared to pregnant women who did not have a family history of DM. The statistical result was statistically significant $(\mathrm{aOR}=2.02 ; 95 \%$ $\mathrm{CI}=1.51$ to $2.70 ; \mathrm{p}<0.001$ ).

Family history of DM was an important factor in most diabetics from the same family who were autosomal dominant. This is in line with a study conducted by Budiarti (2018) that there was a relationship between family history and an increased risk of type $2 \mathrm{DM}$ and it was statistically significant. Family history of DM was associated with the occurrence of preeclampsia. This was proven in a study conducted by Sari (2019) that the factors affecting preeclampsia were related to the mother's medical history, including a family history of hypertension, history of hypertension, and family history of DM.

Family history of DM was associated with GDM. This is in line with a study conducted by Sulistiyah (2015) that pregnant women with a family history of DM (49\%) were a risk factor for diabetes mellitus in pregnancy compared to other risk factors such as a history of recurrent miscarriage (25\%), a history of preeclampsia (14\%), Polyhydramnios (11\%), and IUFD (7\%).

Women who had diabetes during pregnancy had normal glucose homeostasis in the first half of pregnancy. It progressed to relative insulin deficiency during the second half, thus causing hyperglycemia.

A study conducted by Moosazadeh (2017) showed that a family history of diabetes was the main risk factor for Gestational Diabetes Mellitus in Iran. This result was statistically significant aOR 3.46 (95\% $\mathrm{CI}=2.80$ to $4.27 ; \mathrm{p}=0.001)$. In addition, Ali et al, (2016), in their study stated that a family history of diabetes was an independent risk factor for the prevalence of GDM.

The study conducted by Fuji Rachmawati (2016) stated that there was a significant relationship between the family history of DM and GDM in pregnant women at Simpang Timbangan Community Health Center, South Sumatra, Indonesia. The results of the correlation test showed that the p-value was $\leq 0.050$, namely 0.002 . It showed that there was a significant relationship between the family history of DM and GDM in pregnant women.

The result is in line with a study carried out by Choi et al. in Korea (2016). This study was conducted by surveying Korean nurses through an independent interview with a web-based computer. It was developed in consultation with cardiologists, gynecologists, and statisticians. This study showed that family history was a cardiovascular risk factor associated with pregnancy medical disorders such as GHD and GDM in a survey of nurses in Korea. Family history of DM was one of the main risk factors in this study; the results were statistically significant; aOR 2.68 (95\% CI: 1.86-3.86).

Groof et al, (2019) and Njete et al, (2017) examined the risk factors and prevalence of GDM. The result of a study conducted by Groof et al, (2019) estimated that $12.6 \%$ of pregnancies in Kuwait were affected by GDM. Based on national selfreporting, elderly, obesity before pregnancy, family history of T2 DM/GDM, and 
a history of stillbirth/miscarriage were associated with an increased risk of GDM in this study. Njete et al, (2017) stated that the prevalence of GDM was significantly related to the family history of DM (aOR 2.14).

Based on the discussion above, a family history of DM could increase GDM.

The limitation of this study was that there was a publication bias showed in the funnel plot. Language bias occurred because the selected articles were only published in the the English language, thus ignoring articles using other languages. Besides, the researchers used 4 databases only (PubMed, Research Get, Science Direct, and Google Scholar), thus ignoring other search sources.

\section{AUTHOR CONTRIBUTION}

Ummu was the main researcher who selected the topic, investigated, and collected the data. Didik Tamtomo and Bhisma Murti played roles in guiding the writing and reviewing the documents.

\section{CONFLICT OF INTEREST}

This study did not have any conflict of interest.

\section{FUNDING AND SPONSORSHIP}

This study used personal funds from the main researcher.

\section{ACKNOWLEDGEMENT}

We would like to thank the databases provider of PubMed, ResearchGate, Science Direct, Google Scholar.

\section{REFERENCE}

Ali AD, Mehrass AAKO, Al-Adhroey, AlShammakh, Dan Amran (2016). Prevalence and risk factors of gestational diabetes mellitus in Yemen. Int $\mathrm{J}$ Womens Health, 8: 35-41. https://dx.doi.org/10.2147\%2FIJWH.S97502.
American diabetes association clinical practice recommendations 2001. Diabetes Care. 24(1):S1-S133. PMID: 11403001.

American Diabetes Association (2017). Fast facts data and statistics about diabetes. https://professional.diabetes.org/content/fast-facts-data-andstatistics-about-diabetes.

Begum P, Shaha DR, Walid KM (2017). Gestational diabetes mellitus and associated risk factors in patients attending diabetic association medical college hospital in Faridpur. Journal of Enam Medical College. 7(3): 126133. https://doi.org/10.3329/jemc.v7i3.34071.

Budiarty E, Tamtomo DG, Adriani RB (2018). Path analysis on the biopsychosocial determinants of type 2 diabetes mellitus and depression at Dr. Moewardi Hospital, Surakarta. J Epidemiol Public Health.

BilousDan Richard Donelly (2014). Buku Pegangan Diabetes Edisi 4. (Ns. Barrarah Baried, Ed.) (Ke 4). Jakarta: Bumi Medika

Choi DJ, Yoon CH, Lee H, Ahn SY, Chae IH. (2016). The association of family history of premature cardiovascular disease or diabetes mellitus on the occurrence of gestational hypertensive disease and diabetes. PLoS One. 11(12): e0167528. https://doi.org/10.1371/journal.pone.0167528.

Depkes RI (2008). Pedoman pengendalian diabetes melitus dan penyakit metabolik. Jakarta: Direktorat Pengendalian Penyakit Tidak Menular Dan Dirjen Pengendalian Penyakit Dan Penyehatan Lingkungan.

Groof Z, Garashi G, Husain H, Owayed S, Albader S, Mouhsen H, Ziyab (2019). Prevalence, risk factors, and fetomaternal outcomes of gestational diabe- 
Ammutammima et al./ Family History of Diabetes Mellitus and Gestational Diabetes Mellitus

tes mellitus in Kuwait: A cross-sectional study. J Diabetes Res. 2019: 9136250. https://doi.org/10.1155/2019/9136250.

Moosazadeh M, AsemiZ, Lankarani KB, Tabrizi R, Maharlouei N, Naghibzadeh-Tahami, Akbarin M (2017). Family history of diabetes and the risk of gestational diabetes mellitus in Iran: A systematic review and metaanalysis. Diabetes Metab Syndr. 11(1): S99-S104. https://doi.org/10.1016/j.dsx.2016.12.016.

Murti B (2018). Prinsip dan metode riset epidemiologi. Edisi Ke 5. Surakarta: Program Studi Ilmu Kesehatan Masyarakat.

Njete HI, John B, Mlay P, Mahande MJ, Msuya SE (2017). Prevalence, predictors and challenges of gestational diabetes mellitus screening among pregnant women in Northern Tanzania. Trop Med Int Health. 23(2): 236242. https://doi.org/10.1111/tmi.13018.

Prasetyowati U, Tamtomo D, Murti B (2018). Path analysis: Factors associated with self preventive care among patients with type 2 diabetes mellitus in Surakarta. J Health Promot Behav. 3(2): 86-93. https://doi.org/10.26911/thejhpb.2018.03.02.01.

Rahmawati F, Natosba J, (2016). Skrining diabetes melitus gestasional dan faktor risiko. Journal of Sriwijaya Nurs- ing. 3(2): 33-43. https://doi.org/·10$.1037 /$ aoo32982

Sari PW, Budihastuti UR, Pamungkasari EP (2019). Path analysis on the determinants of severe preeclampsia in Surakarta, Central Java. J Maternal Child Health. 4(2): 126-135. https://doi.org/10.26911/thejmch.2019.04.02.08.

Sulistiyah (2015). Faktor pendukung timbulnya resiko gestasional diabetes mellitus pada ibu hamil di BPS Kabupaten Malang. Jurnal Kesehatan Hesti Wira Sakti. (22): 1-14.

Sugianto (2016). Diabetes Melitus Dalam Kehamilan. (Evie Kemala Dewi, Ed.). Jakarta: Erlangga.

Osgood EA (2011). The inter and intrageneration impact of gestasional diabetes on the epidemic of type 2 diabetes. Am J Public Health. 101(1): 173-179. https://dx.doi.org/10.2105\%2FAJPH. 2009.186890.

WHO (2017). World health statistics 2017: Monitoring health for the SDGs. World Health Organization. Https://Doi.Org/10.1017/CBO9781107415324. 004.

Zhang MX, Pan, GT, Guo JF, Li BY, Qin LQ, Zhang ZL (2015). Vitamin D deficiency increases the risk of gestational diabetes mellitus: A meta-analysis of observational studies. Nutrients. 7 (10): 8366-75 https://doi.org/10.339o/nu7105398. 